Yaylacı, Z. \& Büyükalan, F., (2019). Sosyal bilgiler eğitiminde öğretmen görüşüne başvurulan tezlerin tematik açıdan incelenmesi (2005-2017). Bolu Abant İzzet Baysal Üniversitesi Ĕ̈itim Fakültesi Dergisi, 20 (1), 1-19.

$\begin{array}{lll}\text { Makalenin Türü / Article Type } & : \text { Araştırma Makalesi / Researh Article } \\ \text { Geliş Tarihi / Date Received } & : 23.11 .2018 \\ \text { Kabul Tarihi / Date Accepted } & : 15.10 .2019 \\ \text { Yayın Tarihi / Date Published } & : 06.03 .2020 \\ \text { doi https://dx.doi.org/10.17240/aibuefd.2020.20.52925-487045 }\end{array}$

\title{
SOSYAL BİLGILER EĞITIMMINDE ÖĞRETMEN GÖRÜŞÜNE BAŞVURULAN TEZLERİN TEMATİK AÇIDAN İNCELENMESİ (2005-2017)
}

\author{
Zeynep YAYLACI', Sevil BÜYÜKALAN²
}

öz

Bu araştırmanın amacı 2005-2017 yılları arasında Türkiye'de sosyal bilgiler eğitimi alanında öğretmen görüşüne başvurulan lisansüstü tezlerin konu eğilimlerini ortaya koymaktır. Tarama modelinde yapılmış betimsel bir çalışma olan araştırmada sosyal bilgiler eğitimi alanında öğretmen görüşleri doğrultusunda hazırlanan 135 yüksek lisans, 12 doktora tezi olmak üzere toplam 166 tez içerik analizi yöntemi ile analiz edilmiştir. Araştırmada elde edilen sonuçlara göre araştırmacıların en çok sosyal bilgiler öğretimi, öğretimde yaşanan sorunlar, ölçme değerlendirme ve kitaplar (öğrenci çalışma, ders, öğretmen kılavuz) konusunda öğretmen görüşüne başvurdukları görülmüştür. Araştırmacıların öğretmen görüşü almada en az eğilim gösterdikleri konuların ise özel eğitim, öğrenme ortamları, sosyal bilgiler dersine ilişkin tutumlar olduğu sonucuna ulaşılmıştır. Öğretmen görüşü bağlamında en az 2013 yılında en fazla ise 2016 yılında ortaya konulan tezlerin çoğunlukla Gazi, Fırat, Anadolu ve Atatürk Üniversitelerinden verildiği araştırmada elde edilen bir başka sonuçtur. Araştırmacıların öğretmen görüşleri doğrultusunda ortaya koydukları tezlerde en çok nicel yöntemleri tercih ettikleri; fakat son yıllarda nitel yöntemlerle ortaya konulan tezlerin giderek arttığı görülmüştür.

Anahtar Kelimeler: Sosyal Bilgiler, yüksek lisans, doktora, içerik analizi, öğretmen görüşleri

\section{THESIS STUDIES ACCORDING TO THE TEACHERS' OPINION FROM THE THEMATIC POINT OF VIEW IN SOCIAL STUDIES EDUCATION (2005-2017)}

\begin{abstract}
The aim of this study is to present the subject trends of graduate theses applied to teacher's viewpoint in the field of social studies education in Turkey between 2005-2017. In this study, a descriptive study on the scanning model, 135 master's and 12 doctorate thesis prepared in line with the teachers ' directions in the field of social studies education was analyzed with a total of 166 thesis analysis methods. According to the results obtained from the research, researchers mostly applied to teachers ' views on social studies teaching, problems in teaching, assessment and books (student study, lesson, teacher guide). It has been concluded that the subjects that researchers tend to take teachers ' views are special education, learning environments, attitudes towards social studies course. It has been concluded that the subjects that researchers tend to take teachers ' views are special education, learning environments, attitudes towards social studies course. In the context of teacher opinion, at least in 2013 and at most in 2016, the thesis was given mostly from Gazi, Firat, Anadolu and Atatürk universities. The researchers prefer the most quantitative methods in their theses in line with the teachers ' opinions; but in recent years, it has been observed that the thesis presented by qualitative methods is increasing.
\end{abstract}

Keywords: Social Studies, master's, doctorate, content analysis, teacher opinions

\footnotetext{
${ }^{1}$ Gazi Üniversitesi, Gazi Eğitim Bilimleri Enstitüsü, zeynepyylc@gmail.com, @https://orcid.org/0000-0002-4380-3079

${ }^{2}$ Gazi Üniversitesi, Gazi Eğitim Fakültesi, sevilb@gazi.edu.tr, @ https://orcid.org/0000-0002-4955-4405
} 


\section{GíRiş}

Her geçen gün atılan teknolojik, toplumsal, ekonomik ve siyasi adımlarla birlikte eğitim sistemi de yeni yollara yönelmektedir. Dolayısıyla eğitim sisteminin uygulamaya dönük planı olan eğitim programları da bu gelişmelerden en çok etkilenen unsurlardan biri olarak karşımıza çıkmaktadır.

Eğitim programlarını kapsayan köklü değişikliklerden biri 2005 yılında yapılmıştır. Yapılandırmacı anlayışın benimsenmesiyle birlikte sosyal bilgiler programına yansıyan sosyal oluşturmacıllk birçok değişikliğe ortam hazırlamıştır. Öğretimin tek ders kitabına bağllıktan uzaklaştırılması, ünitelerin temalarla oluşturulması, beceri ve değerlerin programın genelinde kazandırılması, sürece dayalı ve buna bağlı olarak alternatif ölçme ve değerlendirme anlayışının benimsenmesi ve her kazanım için tasarlanan örnek etkinlikler (Tay, 2017) programı daha uygulanabilir ve paydaşlarla etkileşimli hale getirmiştir.

Program oluşturma ve uygulama sürecinin en önemli paydaşlarından biri şüphesiz programın uygulayıcıları olan öğretmenlerdir. Bu sebeple araştırmacılar için öğretmenler ve görüşleri 2005 yılında yenilenen sosyal bilgiler programının eksilerini, artılarını, üzerinde tekrar durulması gereken noktalarını kısaca sonuçlarını gösteren en zengin veri kaynaklarından biridir. Bu noktadan hareketle araştırmacıların sosyal bilgiler eğitiminde öğretmen görüşü almada eğilim gösterdikleri konuları incelemek bizlere önemli ipuçları sunacaktır.

Sosyal bilgiler eğitimi alanında ortaya konulan çalışmalara bakıldığında öğretmen görüşüne başvurulan tezlerin incelenmesi üzerine herhangi bir araştırmaya rastlanmamıştır; ancak sosyal bilgiler eğitimi alanında verilen tezler üzerine genel inceleme çalışmaları vardır.

Bu çalışmalardan biri Oruç ve Ulusoy (2008)'un "Sosyal Bilgiler Alanında Yapılan Tez Çalışmaları" adlı makalesidir. Araştırmacılar bu çalışmada 2000-2007 yılları arasında ortaya konulan ve rastgele seçilmiş 100 adet tezi konularına göre incelemişlerdir. En çok çalışılan konunun öğretim yöntem ve teknikleri olduğu bulgusuna ulaşan araştırmacılar ayrıca inceledikleri tezlerde görülen hataları belirtmişlerdir.

Bir diğer çalışma Aksoy, Sönmez ve Merey (2009)'in "Sosyal Bilgiler Öğretiminde Yapılan Lisansüstü Tez Konularının 2005 Yeni Sosyal Bilgiler Öğretim Programına Göre Değișiminin Değerlendirilmesi” adlı bildirileridir. 1998-2004 yılları arasında 44, 2004-2008 yılları arasında verilen 72 tezi inceleyen araştırmacılar, 2005 yeni sosyal bilgiler programının tez konuları üzerine yaptığı etkiyi ortaya koymaya çalışmışlardır.

Tarman, Acun ve Yüksel (2010) tarafından ortaya konulan bir diğer çalışma "Sosyal Bilgiler Eğitimi Alanındaki Tezlerin Değerlendirilmesi” adlı makaledir. 1994-2010 yılları arasında ortaya konulan 335 tezi inceleyen araştırmacılar tezlerin ağılıklı olarak sosyal bilgiler programı üzerine olduğunu ve tezlerin yazılmasında güncel konu ve gelişmelerin takip edilmemesini bir eksiklik olarak ifade etmişlerdir.

Tezlerin incelendiği başka bir çalışma Şahin, Yıldız ve Duman (2011)'ın "Türkiye'de Sosyal Bilgiler Tezleri Üzerine Bir Değerlendirme" adlı makalesidir. Bu kapsamda 1990-2010 yılları arasında verilen 612 tezi inceleyen araştırmacılar en çok çalışılan konunun eğitim programı ve öğretim yöntemleri olduğu bulgusuna ulaşmışlar ve lisansüstü araştırma eğilimlerine ilişkin önemli noktaların altını çizmişlerdir.

\subsection{Araştırmanın Amacı}

Bu araştırmanın amacı 2005-2018 yılları arasında Türkiye'de sosyal bilgiler öğretimi alanında öğretmen görüşüne başvurulan lisansüstü tezlerin konu eğilimlerini ortaya koymaktır. Bu genel amaç çerçevesinde aşağıda yer alan sorulara cevap aranmıştır:

1- Öğretmen görüşleri doğrultusunda ortaya konulan tezlerin konu dağılımı nasıldır?

2- Öğretmen görüşleri doğrultusunda ortaya konulan tezlerin yıllara göre dağılımı nasıldır?

3- Öğretmen görüşleri doğrultusunda ortaya konulan tezlerin üniversitelere göre dağılımı nasıldır?

4- Öğretmen görüşleri doğrultusunda ortaya konulan tezlerin yöntemlere göre dağılımı nasıldır?

5- Öğretmen görüşleri doğrultusunda ortaya konulan tezlerin örneklem grubuna göre dağılımı nasıldır?

6- Öğretmen görüşleri doğrultusunda ortaya konulan tezlerin örneklem büyüklüğüne göre dağılımı nasıldır?

7- Öğretmen görüşleri doğrultusunda ortaya konulan veri analiz tekniklerine göre dağılımı nasıldır?

\subsection{Araştırmanın Önemi}

Sosyal bilgiler eğitimi alanında öğretmen görüşüne başvurulan tezlerin incelemesine ilişkin herhangi bir çalışma yapılmadığından bu çalışmanın öğretmenlerle çalışacak olan araştırmacılara detaylı bilgi sağlayacağı ve ileride yapılacak olan inceleme çalışmalarına katkı getireceği düşünülmektedir. 


\section{YÖNTEM}

Yöntem bölümünde araştırmanın modeli, veri toplama aracı ve elde edilen verilerin analizine ilişkin açıklamalara yer verilmiştir.

\subsection{Araştırmanın Modeli}

Araştırma tarama modelinde yapılmış betimsel bir çalışmadır. Tarama modeli, var olan bir durumun var olduğu şekliyle betimlendiği ve araştırma konusu olan olay, birey ya da nesnenin olduğu gibi tanımlanmaya çalışıldığı bir modeldir (Karasar, 2010, s.77). Bu çalışmada sosyal bilgiler alanında öğretmen görüşüne başvurulan tezlerin düzey, konu, yöntem, örneklem grubu ve büyüklüğü ile kullanılan veri analiz yöntemine göre tasnif edilmiş durumu ortaya konulmaya çalışılmıştır.

\subsection{Veri Toplama Aracı}

Çalışmada veri toplama aracı olarak doküman inceleme formu kullanılmıştır. Öncelikle Ulusal Tez Merkezi’nden çalışmaya konu olacak tezlere ulaşılmıştır. Ulaşılan tezler tez sınıflama kodu, yazarın adı soyadı, tez yılı, tez düzeyi, tez başlığı, yöntem, örneklem grubu, örneklem büyüklüğü ve veri analiz yöntemi başlıklarına göre tasnif edilmiştir.

\subsection{Verilerin Analizi}

Araştırma verilerinin toplanmasında içerik analizi kullanılmıştır. İçerik analizinde temel amaç toplanan verilerden birbirine benzeyenleri belirli temalar etrafında bir araya getirmek ve okuyucunun anlayabileceği çerçevede yorumlamaktır (Yıldırım \&Şimşek, 2016, s. 242). Bu amaç etrafında veriler küçük bilgi etiketleri içerisinde toplanarak kodlanır, elde edilen bilgiler birleştirilir ardından temalar etrafında yorumlanır (Creswell, 2016, s.186). Bu bağlamda aşağıdaki işlem basamakları takip edilmiştir:

İşlem Basamakları:

1- İlk olarak Ulusal Tez Merkezi sayfasından “sosyal bilgiler” ve “öğretmen görüşleri” anahtar kelimeleri ile tarama sonucu 58 teze ulaşılmıştır. Bu sayının öğretmen görüşleri doğrultusunda ortaya konulan tezlerin tamamını vermediği düşünüldüğünden sadece "sosyal bilgiler" anahtar kelimesi ile tarama yapılmış ve 1253 teze ulaşılmıştır.

2- 1253 tez öncelikle tarihe göre tasniflenmiş 2005 yılından önce verilen 202 tez ilk incelemenin dişında tutulmuştur.

3- Kalan 1051 tez başlıklarına göre ayrıntılı olarak incelenmiş ve araştırma konusu dışında kalan 885 tez de çıkarılmış ve öğretmen görüşüne başvurularak ortaya konulan 167 teze ulaşılmıştır. Salt olarak öğretmen adayı, veli ve öğrenci görüşü alınarak ortaya konulan tezler çalışmanın dışında tutulmuştur.

4- Sistemde yer alan tezlerin sınıflama formuna işlenmesinin ardından ilk olarak 167 tezin konu başlıklarına göre 20 genel başlık belirlenmiştir. Her tezin yer aldığı başlık sınıflama formuna yazılmış ve bu doğrultuda uzman görüşüne başvurulmuştur. Uzman görüşleri doğrultusunda 2 başlık daha eklenmiş on tez bu başlıklar altına alınmıştır. Ardından her başlığa bir kod verilerek tezler bu kodlara göre tekrar tasnif edilmiştir.

5- Ayrıca çalışmanın alt amaçlarına uygun olarak tezler yılına, düzeyine, yöntemine, örneklem büyüklüğüne, örneklem grubuna ve veri analiz yöntemine göre ayrı ayrı sınıflandırılmıştır.

6- Sınıflandırma işleminin tamamlanmasının ardından elde edilen veriler önce temel amaç etrafında ardından alt amaçlar etrafında yorumlanmıştır.

\section{BULGULAR}

\subsection{Birinci Alt Probleme İlişkin Bulgular ve Yorum}

“Öğretmen görüşleri doğrultusunda ortaya konulan tezlerin konu dağılımı nasıldır?” alt problemine ilişkin elde edilen veriler Grafik 1'de gösterilmiştir. 


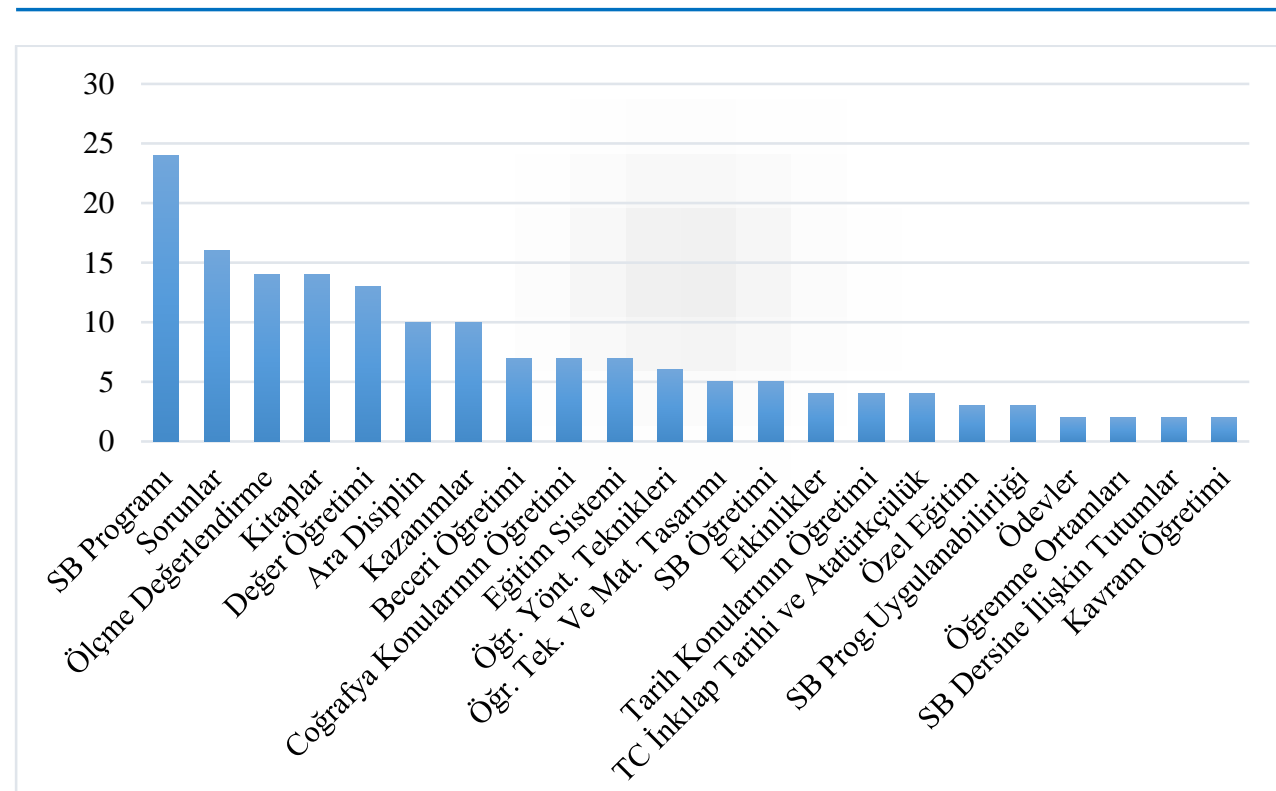

Grafik 1. Sosyal Bilgiler Eğitimi Alanında Öğretmen Görüşüne Başvurulan Tezlerin Konu Dă̆llımları

Grafik 1'de Sosyal Bilgiler Eğitimi alanında öğretmen görüşüne başvurulan tezler 21 başlık altında gruplandırılmıştır. Sosyal bilgiler eğitimi alanında öğretmen görüşüne başvurulan çalışmaların dağılımına bakıldığında "Sosyal Bilgiler Programı (f.24)" başlığı altına alınan çalışmaların çoğunlukta olduğu görülmektedir. Aynı şekilde "Sorunlar (f.16)", "Ölçme Değerlendirme (f.14)", "Kitaplar (f.13)" ve "Değer Öğretimi (f.13)" başlıklarının da araştırmacıların sıklıkla öğretmen görüşüne başvurdukları konular arasında olduğu görülmüştür. Bu konu başlıklarını sırasıyla "Ara Disiplin (f.10)", "Kazanımlar (f.10)","Beceri Öğretimi (f.8)", "Coğrafya Konularının Öğretimi (f.7)”, "Eğitim Sistemi (f.7)”, “Öğretim Yöntem ve Teknikleri (f.6)”, “Öğretim Teknolojileri ve Materyal Tasarımı (f.5)", "Sosyal Bilgiler Öğretimi (f.5)", "Etkinlikler (f.4)”, "Tarih Konularının Öğretimi (f.4)", "TC İnkılap Tarihi ve Atatürkçülük (f.4)", "Özel Eğitim (f.3)", "Sosyal Bilgiler Programının Uygulanabilirliği (f.3)", “Ödevler (f.2)", “Öğrenme Ortamları (f.2)”, "Sosyal Bilgiler Dersine İlişkin Tutumlar (f.2)", "Kavram Öğretimi (f.2)” başlıkları takip etmektedir.

"Sosyal Bilgiler Programı" başlığı altına alınan tezlerin dağılımına bakıldığında çoğunluğunu 2005 yılında yenilenen müfredat ile birlikte 4 ve 5.sınıf sosyal bilgiler programına yönelik öğretmen görüşüne başvurulan tezler oluşturmaktadır (Ayten, 2006; Aydın, 2007; Çetin, 2007; Kılıçoğlu, 2007; Ece, 2007; Kalaycıŏlu; 2007, Yazar, 2008; Sağlam, 2014a). 6 ve 7.sınıf sosyal bilgiler programına ilişkin öğretmen görüşlerini içeren tezlere de 2007 yılından itibaren sıklıkla rastlanmaktadır (Erköse, 2007; Özdal,2007; Öztürk, 2009; Başoğlu, 2009; Polat, 2012). 2016 yılından itibaren doğrudan programa ilişkin öğretmen görüşüne başvurulan tezlere rastlanmamıştır. Bu durumun tezlerin dışında programla ilgili ortaya konulan diğer yayın türlerinin sayıca fazla oluşu ve 2005 programına ilişkin literatür boşluklarının doldurulmuş olmasından kaynaklandığını söyleyebiliriz.

Araştırmacıların öğretmen görüşüne başvurdukları bir başka konu başlığı sosyal bilgiler eğitiminde karşılaşılan sorunlardır. Tezler programın uygulayıcıları olan öğretmenlerin karşılaştıkları sorunlar bağlamında incelendiğinde 2006 yılından itibaren çalışmaların olduğu görülmektedir. Bu başlık altında yer alan tezler sosyal bilgiler öğretiminde karşılan sorunlar şeklinde başlıklandırıldığı gibi (Tahiroğlu, 2006; Alataş, 2008; Akşit, 2011; Akmehmetoğlu, 2014; Karaca, 2017), coğrafya konularının öğretiminde karşılaşılan sorunlar (Salik, 2007; Aktaş, 2010), tarih konularının öğretiminde karşılaşılan sorunlar (Göç, 2008), öğretmenlerin kullandıkları yöntemlere ilişkin sorunlar (Polat, 2006; Erdoğdu, 2010) gibi spesifik olarak da çalışılmıştır.

Ölçme değerlendirme süreci programın eksik yönlerinin tamamlanması açısından dönüt veren ve üzerinde durulması gereken en mühim konulardandır. Dolayısıyla sosyal bilgiler eğitiminde ölçme değerlendirme sürecine ilişkin öğretmen görüşüne başvurulan tezlerin sayısı da giderek artmaktadır. 2005 yılından itibaren bu başlık altında verilen tezler incelendiğinde eski ve yeni program arasında ölçme değerlendirme farklılıklarına ilişkin (Pınarbaş1, 2007); Ataman, 2007), öğretmenlerin tercih ettikleri değerlendirme yöntemlerine ilişkin (Turan, 2010), alternatif ölçme değerlendirme yöntemlerine ilişkin (Kabak, 2009; Hatuk, 2010; Bayram, 2012; Karasu, 2012) öğretmen görüşüne başvurulduğu görülmektedir.

Araştırmacıların öğretmen görüşü aldıkları bir diğer konu sosyal bilgiler dersinde kullanılan ders, çalışma ve öğretmen kılavuz kitaplarıdır. Bu bağlamda ortaya konan tezler incelendiğinde en çok ders kitapları ile ilgili tezlere (Yıldız, 2005; Kulantaş, 2007; Şahin, 2010; Baki, 2012; Güler, 2016; Taşkın, 2017) ve öğretmen kılavuz kitapları ile ilgili tezlere (Yıldızhan, 2010; Yılmaz, 2014) rastlanmaktadır. 
Sosyal bilgiler programının yapısını oluşturan en önemli ögelerden biri olan değerlere ilişkin tezler, kitaplarla ilgili ortaya konan tezlerle birlikte, öğretmen görüşüne başvurulan araştırmalar arasında dördüncü sırada yer almaktadır. Çeşitli sınıf düzeylerinde değer öğretimine ilişkin olarak (Can, 2008; Kılcan, 2009; Uçar, 2009; Kınasakal, 2012; Baysal, 2013; Batmaca, 2016) öğretmen görüşüne başvurulduğu gibi, bir değerin öğretimi ile ilgili de öğretmen görüşleri alınmıştır (Tepecik, 2008; Çelik, 2010; Ergin, 2011; Avc1, 2015;) Vatanseverlik, sorumluluk, estetik, doğal çevreye duyarlılık tez konusu yapılan değerlerden bazılarıdır. 2016 yılından itibaren değer eğitimine ilişkin öğretmen görüşüne başvurulan tezlere rastlanmamıştır.

“Ara Disiplin” başlığı 2017 Sosyal Bilgiler Programına kadar tüm programlarda yer aldığından araştırmacıların öğretmen görüşü alarak değerlendirdikleri konu başlıklarından biri olmuştur. Bu bağlamda ortaya konulan tezler incelendiğinde insan hakları ve vatandaşlık eğitimi (Ersoy, 2007; Başaran, 2007; Çelik, 2009), deprem bilinci (Çakar, 2008), kariyer bilinci (Gezer, 2015), girişimcilik (Arslan, 2016) ara disiplinlerine ilişkin tezler ortaya konulduğu görülmüştür.

Sosyal bilgiler programının en temel başlıklarından biri olan kazanımlar da araştırmacıların eğilim gösterdikleri konulardan biridir. Bu başlık altında verilen tezler incelendiğinde bir ünitenin ya da konunun içerdiği kazanımlara ilişkin (Ata, 2007; Aydoğan, 2010; Badem, 2012; Çelik, 2016) ve farklı sinıf düzeylerinde uygulanan öğretim programlarının kazanımlarına ilişkin (Kara, 2013; Sağlam, 2014b) öğretmen görüşüne başvurulduğu görülmüştür.

"Beceri Öğretimi” başlığı altında verilen tezler incelendiğinde araştırmacıların spesifik olarak belirli beceriler üzerine öğretmen görüşüne başvurdukları görülmüştür. Düşünme becerileri (Özdemir, 2006), mekânı algılama becerisi (Safi, 2010), harita okuryazarlığı (Cendek, 2015; Abbak, 2016) bu becerilerdendir.

Sosyal bilgilerin alt disiplinlerinden olan coğrafya ve tarih konularının öğretimine ilişkin öğretmen görüşüne başvurulan tezlerin dağılımına bakıldığında coğrafya konularının öğretimi üzerine yapılan çalışmaların daha fazla olduğu görülmektedir. Coğrafya konularının öğretimi ile ilgili çalışmalara bakıldığında çoğunlukla 6 ve 7.sınıf programında yer alan coğrafya konularının öğretiminde öğretmen görüşlerine başvurulduğu görülmektedir (Nalçacı, 2006; Kahriman, 2008; Urçar, 2011). Özünal (2015) Coğrafya konularının öğretiminin kimlik inşası ve vatandaşlık bilincine katkısına ilişkin öğretmen görüşü alarak farklı bir pencereden öğretim sürecini değerlendirmiştir.

Eğitim sistemi başlığı altında yer alan çalışmalara bakıldığında araştırmacıların ders denetimi (Yıldırım, 2007), 4+4+4 eğitim süreci (Demir, 2014), çok kültürlü eğitim (Bahadır, 2016), branş derslik sistemi (Sayar, 2016) gibi konulara ilişkin öğretmen görüşlerine başvurdukları görülmektedir. Bu durum araştırmacıların yenilik ve gelişmelerle ilgili öğretmenlerin görüşünü önemli bulduklarına işaret etmektedir; ancak önemli diyebileceğimiz eğitime yön verebilecek bu konulara ilişkin çalışmaların sayısı hala yeterli değildir.

Yapılan çalışmalar sosyal bilgiler eğitimi alanında araştırmacıların öğretim yöntem ve tekniklerine ilişkin fazlaca çalışma ortaya koyduklarını göstermektedir; fakat bu konuda öğretmen görüşüne başvurulan çalışmaların oldukça az olduğu görülmüştür. Bu azlığın sebebi olarak araştırmacıların öğretmen görüşünden ziyade ön test- son test gruplu uygulamalarla öğretim yöntem ve tekniklerinin etkililiğini ortaya koymaya eğilimli olmaları olarak gösterilebilir. Öğretmen görüşüne başvurulan tezlere bakıldığında ise gezi-gözlem yönteminin sık çalışılmış olması dikkat çekicidir (Erdem, 2007; Aktaş; 2016; Şan; 2016). Bozkurt (2017) ise güncel olayların sosyal bilgilerde kullanımına ilişkin öğretmen görüşlerine başvurmuştur.

Sosyal bilgiler eğitiminde öğretim teknolojileri ve materyal tasarımı konusunda öğretmen görüşüne başvurulan çalışmalar incelendiğinde önemli birkaç bulgu karşımıza çıkmaktadır. Araştırmacıların teknoloji kullanımına yönelik çalışma eğilimlerinin 2016 yılından itibaren yoğunlaştığı görülmüştür. Teknolojide yaşanan gelişmeler ve bu gelişmelerin eğitime entegre edilmesiyle ortaya çıkan sonuçları programın uygulayıcıları aracılı̆̆ıyla ortaya koyma isteği, bu durumun nedeni olarak gösterilebilir. Bu bağlamda tezlere bakıldığında araştırmacıların öğretim teknolojileri (Kara, 2016), bilgi teknolojileri (Aydın, 2016), EBA (Kartal, 2017) gibi konularda öğretmen görüşü aldıkları görülmüştür.

Sosyal bilgiler programında yer alan etkinliklere ilişkin ortaya konulan tezlere bakıldığında araştırmacıların program değişimden sonra ilk yıllarda etkinliklerin uygulanabilirliğine ilişkin öğretmen görüşlerine başvurdukları görülürken (Kamber, 2007) sonraki yıllarda uygulanan etkinliklere ilişkin öğretmen görüşü aldıkları görülmüştür (Demir, 2010; Hallaç, 2011; Taş, 2015).

Özel eğitim, sosyal bilgiler programının uygulanabilirliği, ödevler, öğrenme ortamları, derse ilişkin tutumlar ve kavram öğretimi konuları ise araştırmacıların öğretmen görüşü almada az tercih ettiği konular arasında yer almaktadır. Sosyal bilgiler eğitimi bağlamında özel eğitim ve öğrenme ortamları konularında hâlihazırda çok fazla çalışmanın olmaması, derse ilişkin tutum ve ödevler konusunda da öğretmenlerden çok öğrenci görüşlerine başvuruluyor olması bu durumun nedenleri arasında gösterilebilir. 


\section{2.İkinci Alt Probleme İlişkin Bulgular ve Yorum}

“Öğretmen görüşleri doğrultusunda ortaya konulan tezlerin yıllara göre dağılımı nasıldır?” alt problemine ilişkin elde edilen veriler Grafik 2'de gösterilmiştir.

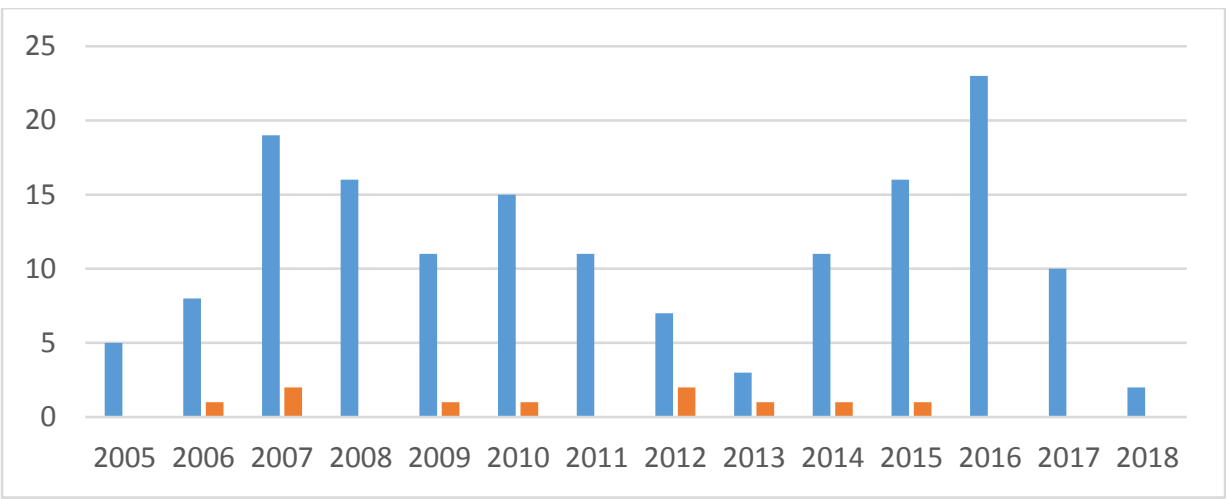

Grafik 2. Sosyal Bilgiler Eğitimi Alanında Öğretmen Görüsüne Başvurulan Tezlerin Yıllara Göre Dağıllmları

Grafik 2 incelendiğinde sosyal bilgiler eğitimi alanında öğretmen görüşüne başvurulan tezlerin sayısı yıllara göre değişim gösterdiği görülmektedir. 2004 yılında hazırlanıp 2005 yılında uygulamaya konulan yeni öğretim programları ile birlikte sosyal bilgiler eğitimi alanında da yeni programların uygulanması, eksileri ve artılarına ilişkin öğretmen görüşlerine başvurulmuştur. Bu tezlere 2006 yılından itibaren rastlanmakla birlikte 2007 yllında (f.21) sayıca artış göstermiştir. 2010 yılına kadar öğretmen görüşüne başvurulan tezlerde düşüş yaşanırken 2010 yılında artmıştır (f.16). 2010 yılından itibaren azalmaya başlayan tezler 2013 yılında en düşük sayıya ulaşmıştır (f.4). Giderek artan ve 2016 yılında en yüksek rakama (f.23) ulaşan tezler 2017 yılında azaldığ görülmektedir. Ayrıca 2005-2017 arasında her yıl yüksek lisans tezi verilmişken doktora tezleri bazı yıllarda verilmiştir.

Doktora düzeyinde araştırmacıların yeni içerikler ortaya koyma istekleri farklı konu ve araştırma gruplarına yönelmelerine neden olurken yüksek lisans düzeyinde içerik üretmekten ziyade araştırmacıdan bilimsel araştırma sürecini doğru şekilde uygulaması beklendiğinden yüksek lisans yapan araştırmacıların öğretmen görüşüne başvurulan tezlere daha çok eğilim gösterdiği söylenebilir.

2017 y1lında sosyal bilgiler programında köklü değişikliklerin olduğu göz önünde bulundurulursa 2018-2019'da program uygulayıcıları olan öğretmenlerin görüşleri doğrultusunda ortaya konulan tezlerin sayısında artış yaşanabileceği beklenmektedir.

\section{3.Üçüncü Alt Probleme İlişkin Bulgular ve Yorum}

“Öğretmen görüşleri doğrultusunda ortaya konulan tezlerin üniversitelere göre dağılımı nasıldır?” alt problemine ilişkin elde edilen veriler Grafik 3’te gösterilmiştir.

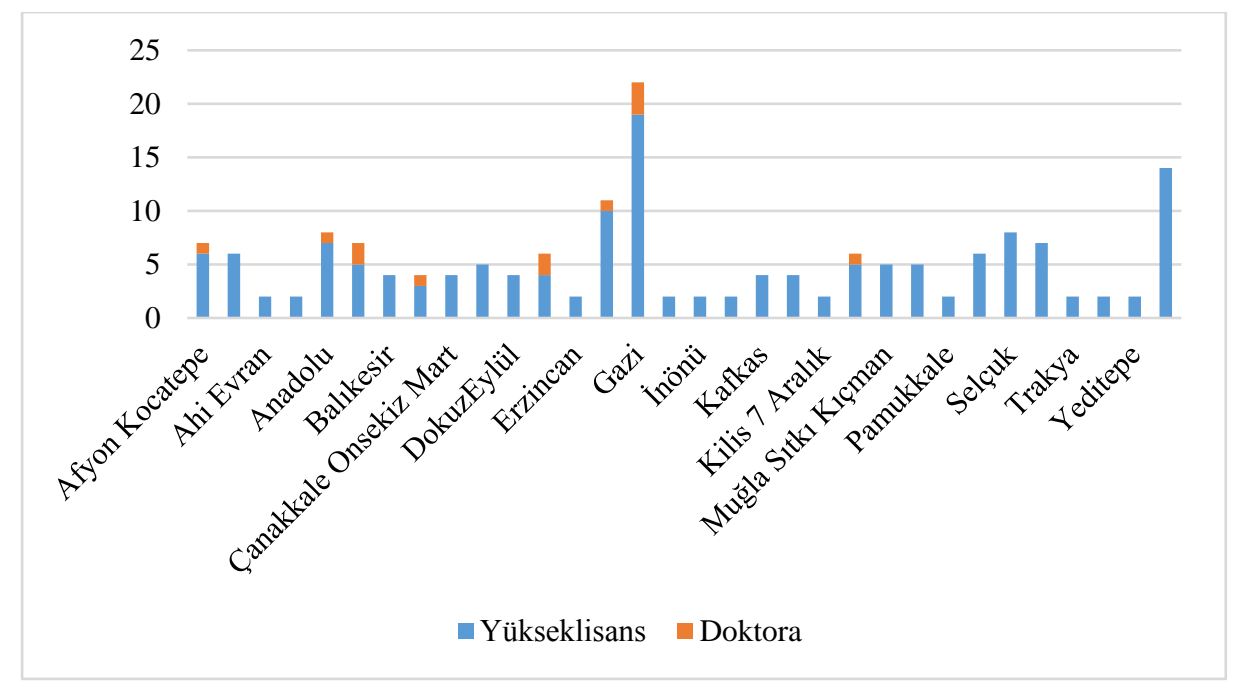

Grafik 3. Sosyal Bilgiler Eğitimi Alanında Öğretmen Görüşüne Başvurulan Tezlerin Üniversitelere Göre Dağıllımları 
Grafik 3 incelendiğinde öğretmen görüşleri doğrultusunda sosyal bilgiler eğitimi alanında verilen tezlerin çoğunluğunu yüksek lisans tezlerinin (f.154) oluşturduğu görülürken doktora tezlerinin oldukça az (f.12) olduğu görülmektedir.

Sosyal Bilgiler Eğitimi alanında öğretmen görüşüne başvurulan tezlerin üniversitelere göre dağılımı incelendiğinde dağılımın büyük bir oranına Gazi Üniversitesi’nin (f.22) sahip olduğu görülmektedir. Gazi Üniversitesini sırayla Fırat Üniversitesi (f.11), Selçuk Üniversitesi (f.8), Anadolu Üniversitesi (f.8), Atatürk Üniversitesi (f.7), Afyon Kocatepe Üniversitesi (f.7), Sakarya Üniversitesi (f.6), Tokat Gaziosmanpaşa Üniversitesi (f.7), Niğde ÖHD Üniversitesi (f.5), Çukurova Üniversitesi (f.5) ve diğer üniversiteler takip etmektedir.

Yüksek lisans ve doktora tezi bağlamında dağılım incelendiğinde en çok yüksek lisans ve doktora tezinin yine Gazi Üniversitesinden çıktığı görülmektedir. Yüksek lisans tezlerine göre dağılım incelendiğinde Fırat Üniversitesi, Anadolu Üniversitesi, Atatürk Üniversitesi, Selçuk Üniversitesi, Sakarya Üniversitesinin ilk sıralarda yer aldığı görülürken tabloda “diğer” olarak belirtilen üniversitelerden birer tez verilmiştir.

Gazi Üniversitesinden sonra öğretmen görüşleri doğrultusunda sosyal bilgiler eğitimi alanında doktora tezlerinin ortaya konulduğu diğer üniversiteler ise Atatürk Üniversitesi, Afyon Kocatepe Üniversitesi, Bolu Abant İzzet Baysal Üniversitesi, Dumlupınar, Marmara ve Firat Üniversiteleridir.

\subsection{Dördüncü Alt Probleme İlișkin Bulgular ve Yorum}

“Öğretmen görüşleri doğrultusunda ortaya konulan tezlerin araştırma yöntemlerine göre dağılımı nasıldır?” alt problemine ilişkin elde edilen veriler Grafik 4'de gösterilmiştir.

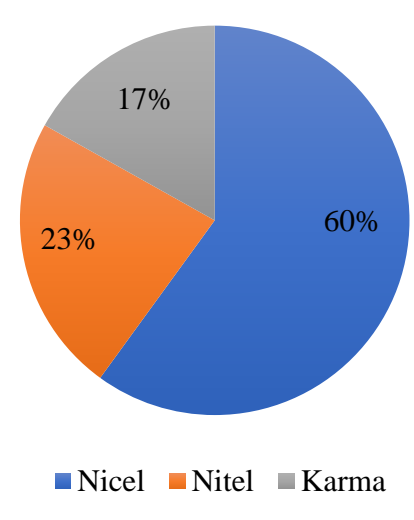

Grafik 4. Sosyal Bilgiler Ĕgitimi Alanında Öğretmen Görüşüne Başvurulan Tezlerin Araştırma Yöntemlerine Göre Dağllımlart

Grafik 4'te sosyal bilgiler eğitimi alanında öğretmen görüşleri alınarak ortaya konulan tezlerin araştırma yöntemlerine göre dağılımına bakıldığında \%60'ının nicel yöntemi, \%23'ünün nitel yöntemleri ve \%17'sinin karma yöntemi kullandığı görülmektedir.

Öğretmen görüşleri doğrultusunda ortaya konulan tezlerde kullanılan araştırma yöntemlerinin yıllara göre dağılımına ilişkin elde edilen veriler Grafik 5 'te gösterilmiştir. 


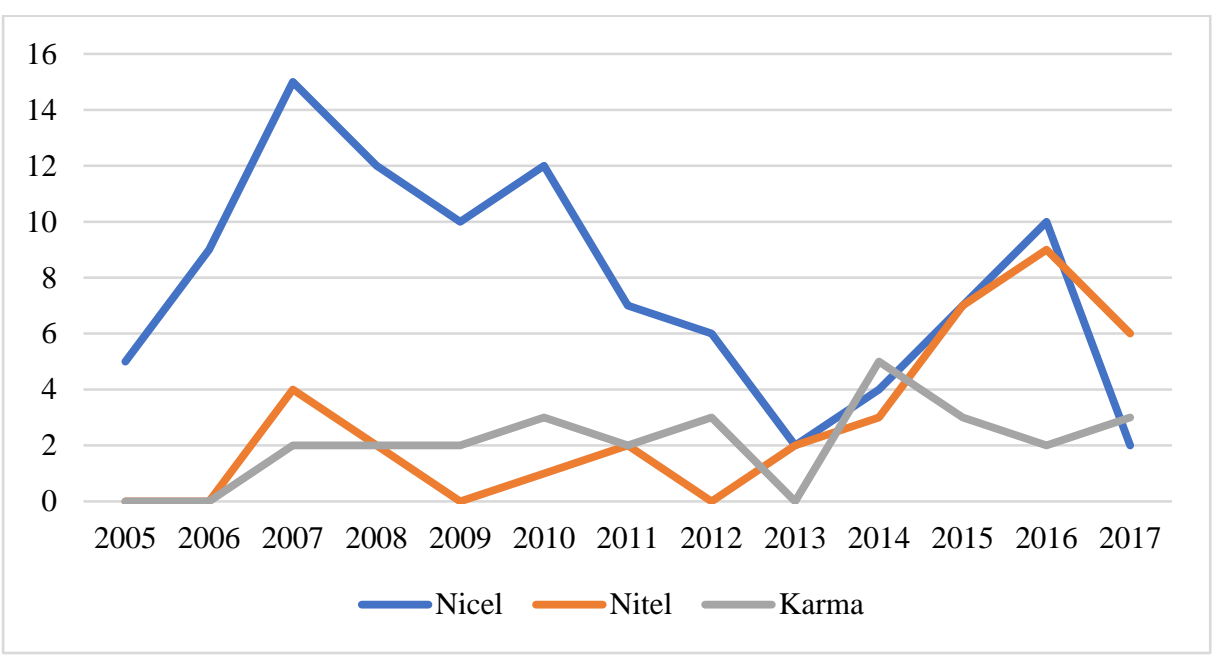

Grafik 5. Sosyal Bilgiler Eğitimi Alanında Öğretmen Görüşüne Başvurulan Tezlerde Kullanılan Yöntemlerin Yıllara Göre Dağıllımları

Grafik 5 incelendiğinde sosyal bilgiler eğitimi alanında öğretmen görüşüne başvurulan tezlerde kullanılan yöntemlerin dağılımı önemli bulgular vermektedir. Nicel yöntemlerin kullanıldığı tezlerin 2005-2017 yılları arasında her yıl kullanıldığ 1 görülürken nitel yöntemlerin kullanıldığ 1 tezlerin 2006 yılından itibaren verildiği ve 2012 yılından itibaren ise nitel yöntemlere olan eğilimi giderek arttığ görülmektedir. Karma yöntemlerin kullanıldığı tezler ise 2007 yılından itibaren görülmekte olup yaklaşık yedi yıldan sonra 2014 yılında en yüksek seviyesine ulaştığg görülmektedir. Dolayısıyla karma yöntemler kullanılarak ortaya konulan tezlerin hala en büyük orana sahip olduğu, nitel çalışmaların popülaritesinin giderek arttığı ve karma yöntemlerin de seviyesinin artacağını söyleyebiliriz.

\subsection{Beşinci Alt Probleme İlişkin Bulgular ve Yorum}

“Öğretmen görüşleri doğrultusunda ortaya konulan tezlerin araştırma yöntemlerine göre dağılımı nasıldır?” alt problemine ilişkin elde edilen veriler Grafik 6' da gösterilmiştir.

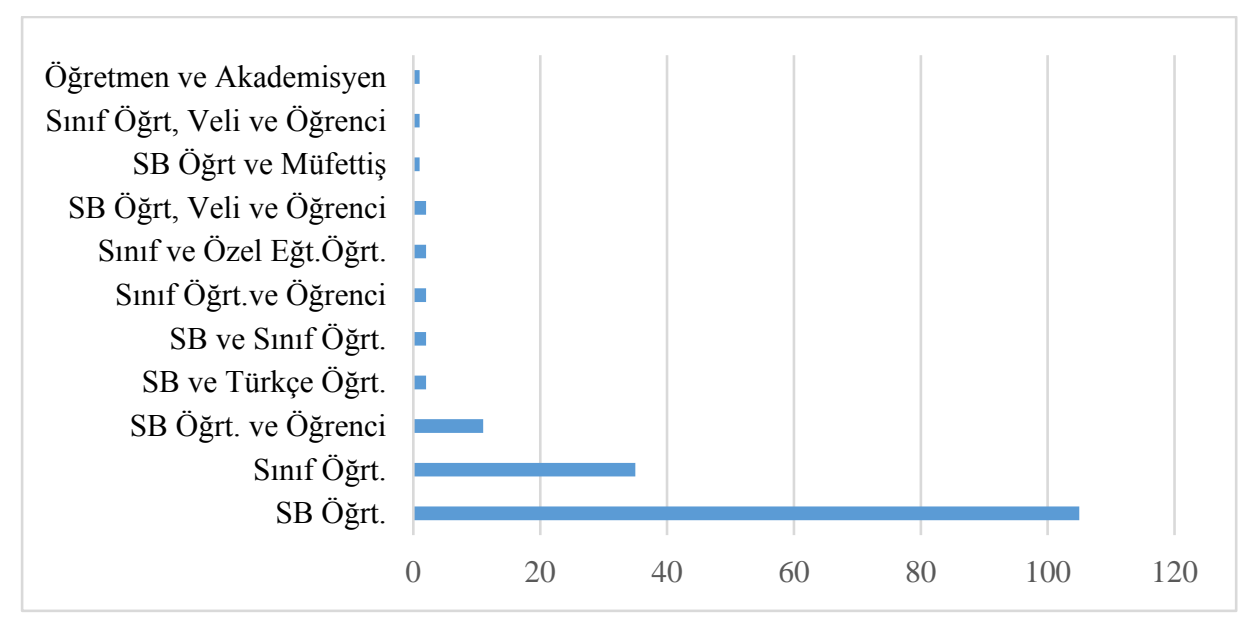

Grafik 6. Sosyal Bilgiler Ĕ̆itimi Alanında Öğretmen Görüşüne Başvurulan Tezlerin Örneklem Gruplarına Göre Dă̆llımları

Sosyal Bilgiler Eğitimi alanında öğretmen görüşüne başvurularak ortaya konulan çalışmalarda tercih edilen örneklem gruplarının dağılımına bakıldığında ilk sırayı sosyal bilgiler eğitimi konusuyla ilişkili olduğunda sosyal bilgiler öğretmenleri oluşturmaktadır. Programın birinci ve ikinci kademede uygulanıyor olmasından ötürü ilk kademede sosyal bilgiler öğretimi yapan sınıf öğretmenleri araştırmacıların ikinci olarak tercih ettikleri örneklem grubunu oluşturmaktadır. Ödevler ve ders kitapları başlığı altına alınan tezler de sosyal bilgiler öğretmenleri ile birlikte öğrencilerin de görüşüne başvuran araştırmacıların (Kulantaş, 2007; Yücel, 2008; Şahin, 2015; ), derse ilişkin tutum gibi farklı çevre ve süreçlerini içeren çalışmalara veli, öğrenci ve öğretmen gruplarını dâhil ettikleri 
(Karadeniz, 2012) görülmüştür. Dolayısıyla konunun bağlamı ve ilişkisine göre araştırmacıların öğretmenler dışında ek olarak farklı gruplarla çalıştıkları görülmektedir.

\subsection{Altıncı Alt Probleme İlişkin Bulgular ve Yorum}

“Öğretmen görüşleri doğrultusunda ortaya konulan tezlerin örneklem büyüklüklerine göre dağılımı nasıldır?” alt problemine ilişkin elde edilen veriler Grafik 7'de gösterilmiştir.

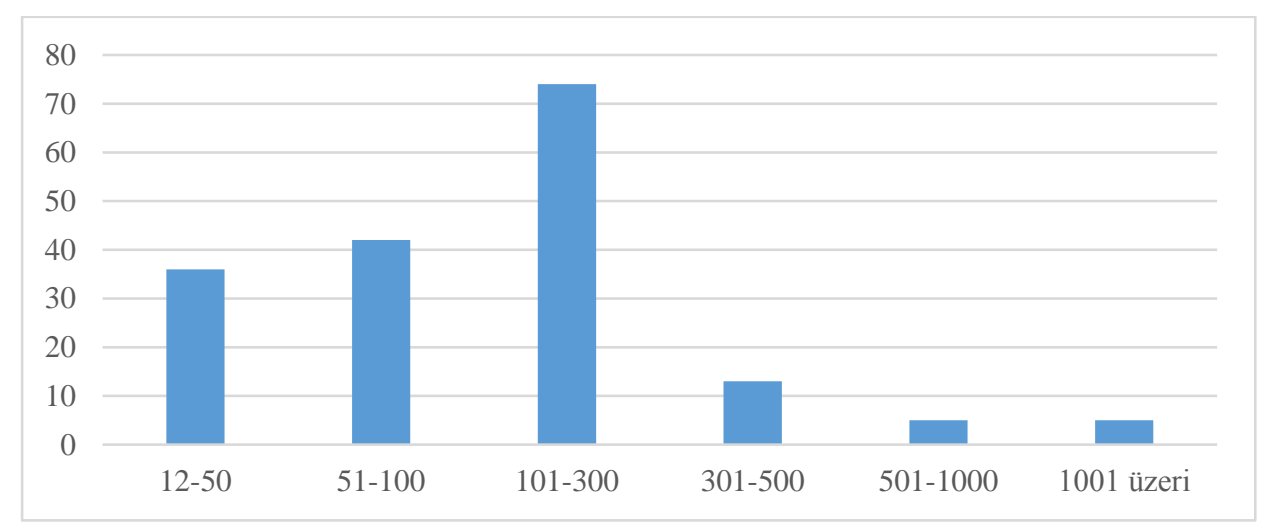

Grafik 7. Sosyal Bilgiler Ĕ̆gitimi Alanında Öğretmen Görüşüne Başvurulan Tezlerin Örneklem Büyüklüklerine Göre Dă̆llımları

Grafik 7'ye bakıldığında Sosyal Bilgiler Eğitimi alanında öğretmen görüşüne başvurulan tezlerin örneklem ve çalışma gruplarının büyüklükleri incelendiğinde büyük çoğunluğun 101-300 arasında (f.74) olduğu, bu sayıyı sirayla 51-100 (f.42) ve 12-50 (f.36) arasında oluşturulan örneklem grupları takip etmektedir. Örneklem büyüklüğünü 501-1000 ve 1001 üzerinde (f.5) oluşturan tezlerin sayısının ise oldukça az olduğu görülmektedir.

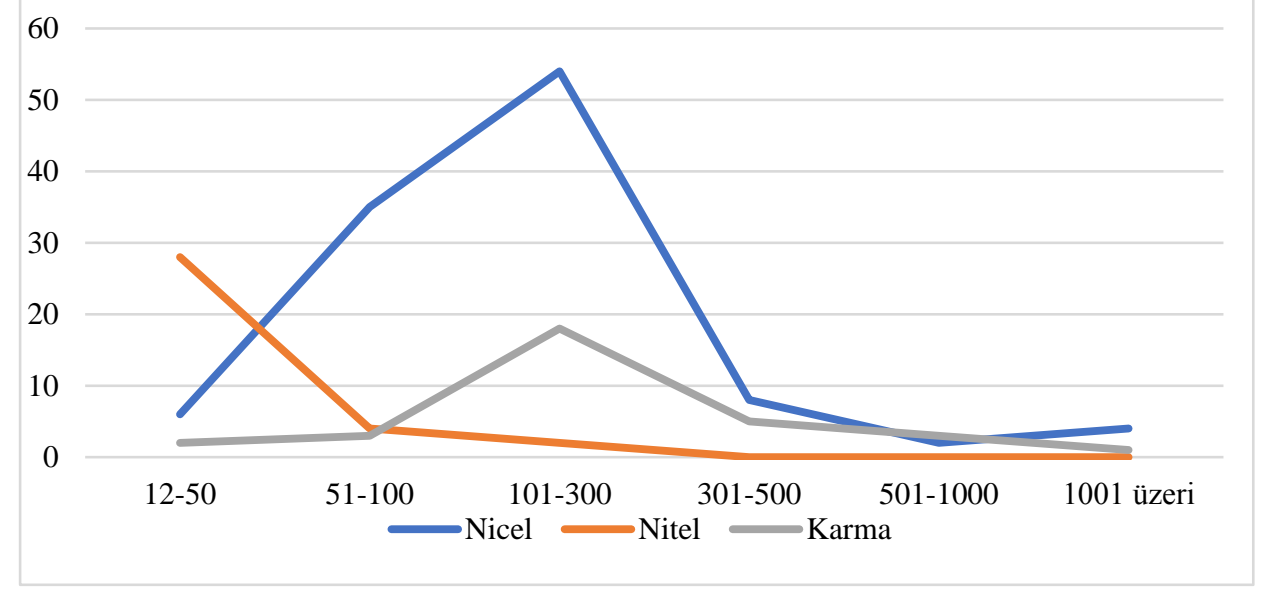

Grafik 8. Sosyal Bilgiler Eğitimi Alanında Öğretmen Görüşüne Başvurulan Tezlerin Yöntemlerine Göre Tercih Edilen Örneklem Büyüklüğ̈̈ Dağılımları

Grafik 8'e göre sosyal bilgiler eğitimi alanında öğretmen görüşlerinin alındığı tezlerin yöntemleri bağlamında örneklem gruplarının dağılımına bakıldığında nicel yöntemli çalışmalarda örneklem grubunun en az 501-1000 kişi arasında en fazla 101-300 kişi arasında olduğu görülmektedir. Nicel yöntemli çalışmalarda en az örneklem grubuna sahip tezde 34, en fazla örneklem grubuna sahip tezde 3019 kişi ile çalışıldığ görülmüştür. Nitel yöntemin kullanıldığ1 çalışmalarda araştırmacıların en çok 12-50 arasında bir değerde örneklem grubu oluşturdukları görülürken en az örneklem grubuna sahip tezde 6, en fazla örnekleme sahip tezde 153 kişi ile çalışıldığ 1 görülmüştür. Karma yöntemin kullanıldığı tezlerde ise araştırmacıların 101-300 arasında örneklem grubu oluşturdukları görülürken en az örnekleme sahip tezde 12, en fazla örnekleme sahip tezde 1380 kişi ile çalışıldığ görülmüştür. 


\subsection{Yedinci Alt Probleme İlişkin Bulgular ve Yorum}

“Öğretmen görüşleri doğrultusunda ortaya konulan tezlerin veri analiz yöntemlerine göre dağılımı nasıldır?” alt problemine ilişkin elde edilen veriler Grafik 9'de gösterilmiştir.

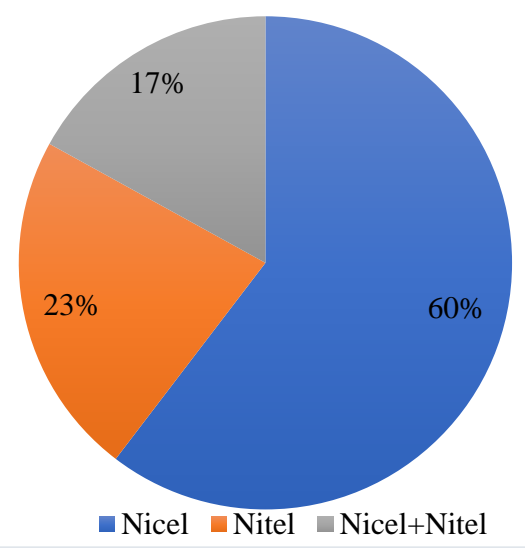

Grafik 9. Sosyal Bilgiler Eğitimi Alanında Öğretmen Görüşüne Başvurulan Tezlerin Analiz Yöntemlerine Göre Dağıllımları

Sosyal bilgiler eğitimi alanında öğretmen görüşlerinin alındığı tezler veri analizi bağlamında incelendiğinde \%60'inda nicel veri analiz yöntemlerinin kullanıldı̆̆ görülürken \%23'ünde nitel veri analiz yöntemlerinin görülmektedir. Karma yöntemin kullanıldığı araştırmalarda ise kullanılan yöntemlere göre nitel ve nicel veri analiz teknikleri bir arada kullanılmıştır. Elde edilen verilere bakıldığında nitel ve karma çalışmaların son yıllarda popüler olmasına rağmen nicel analizin halen en çok tercih edilen analiz yöntemi olduğu sonucuna ulaşılabilir.

\section{TARTIŞMA ve SONUÇ}

Araştırmada elde edilen sonuçlara göre;

Sosyal Bilgiler Eğitimi alanında öğretmen görüşüne başvurulan tezlerin dağılımına bakıldığında \%93'ünün yüksek lisans, \%7'sinin doktora tezi olduğu görülmüştür. Doktora düzeyinde araştırmacıların yeni içerikler ortaya koyma istekleri farklı konu ve araştırma gruplarına yönelmelerine neden olurken yüksek lisans düzeyinde içerik üretmekten ziyade araştırmacıdan bilimsel araştırma sürecini doğru şekilde uygulaması beklendiğinden yüksek lisans yapan araştırmacıların öğretmen görüşüne başvurulan tezlere daha çok eğilim gösterdiği söylenebilir.

Ortaya konulan tezlerin konu dağılımları incelendiğinde araştırmacıların en çok "sosyal bilgiler programı", "sosyal bilgiler öğretiminde karşılaşılan sorunlar", "ölçme değerlendirme" ve "kitaplar" konularında öğretmen görüşüne başvurdukları ortaya çıkmıştır. Tarman, Acun ve Yüksel (2010) de çalışmalarında sosyal bilgiler eğitimi alanında verilen tezlerin çoğunlukla sosyal bilgiler programı, sosyal bilgiler öğretimin karşılaşılan güçlükler ve ders kitabı incelemeleri konularında yoğunlaştığını ortaya koymuşlardır. Aynı çalışmada öğrenci, öğretmen ve veli görüşlerini bir konu başlığ konulduğunun da altını çizmişlerdir. Yine aynı şekilde Geçit ve Kartal'ın (2010) çalışmasında sosyal bilgiler eğitimi alanında çalışan araştırmacıların sosyal bilgiler programı ve kitap incelemelerine olan eğilimlerinin fazla olduğu görülmüştür.

Araştırmacıların ara disiplin, kazanımlar, beceri öğretimi, coğrafya konularının öğretimi, eğitim sistemi, öğretim yöntem ve teknikleri, öğretim teknolojileri ve materyal tasarımı, sosyal bilgiler öğretimi, etkinlikler, tarih konularının öğretimi, TC İnkılap Tarihi ve Atatürkçülük, özel eğitim, sosyal bilgiler programının uygulanabilirliği, ödevler, öğrenme ortamları, derse ilişkin tutumlar ve kavram öğretimi konularını öğretmen görüşü almada daha az tercih ettikleri ortaya çıkmıştır. Sosyal bilgiler eğitimi bağlamında özel eğitim ve öğrenme ortamları konularında hâlihazırda çok fazla çalışmanın olmaması, derse ilişkin tutum ve ödevler konusunda da öğretmenlerden çok öğrenci görüşlerine başvuruluyor olması bu durumun nedenleri arasında gösterilebilir.

Oruç ve Ulusoy (2008) da sosyal bilgiler öğretimi alanında yapılan tez çalışmalarını inceledikleri çalışmada kavram öğretimi, materyal kullanımı, değer-beceri kazandırma konularının oldukça az çalışıldığını vurgulamışlardır.

Sosyal Bilgiler Eğitimi alanında öğretmen görüşüne başvurulan tezlerin üniversitelere göre dağılımı incelendiğinde hem yüksek lisans hem doktora tezi bağlamında en çok tezin Gazi Üniversitesinden çıktı̆̆ 
görülmüştür. Yüksek lisansa göre oldukça az sayıda olan doktora tezinin verildiği diğer üniversiteler ise Atatürk Üniversitesi, Afyon Kocatepe Üniversitesi, Bolu Abant İzzet Baysal Üniversitesi, Dumlupınar, Marmara ve Firat Üniversiteleridir. Şahin, Yıldız ve Duman'ın (2011) araştırma bulgularında da Gazi, Marmara, Atatürk gibi üniversitelerde verilen tez sayısının diğer üniversiteler göre oldukça fazla olduğu ortaya çıkmıştır.

Öğretmen görüşüne başvurulan tezlerde nicel yöntemlerin 2005-2017 yılları arasında her yıl kullanıldı̆̆ görülürken nitel yöntemle çalışılan tezlerin 2006 yılından itibaren verildiği ve 2012 yılından itibaren ise nitel yöntemlere olan eğilimi giderek arttığı ortaya çıkmıştır. Karma yöntemlerin kullanıldığı tezler ise 2007 yılından itibaren görülmekte olup yaklaşık yedi yıldan sonra 2014 yılında en yüksek seviyesine ulaştığı görülmektedir. Dolayısıyla karma yöntemler kullanılarak ortaya konulan tezlerin hala en büyük orana sahip olduğu, nitel çalışmaların da giderek arttığı görülmüştür.

Araştırmada sosyal bilgiler eğitimi alanında öğretmen görüşüne başvurularak ortaya konulan tezlerde tercih edilen örneklem gruplarının dağılımına bakıldığında ilk sırayı sosyal bilgiler öğretmenleri oluşturduğu görülmüştür. Programın birinci ve ikinci kademede uygulanıyor olmasından ötürü ilk kademede sosyal bilgiler ögretimi yapan sınıf öğretmenleri araştırmacıların ikinci olarak tercih ettikleri örneklem grubunu oluşturmaktadır. Ödevler ve ders kitapları başlığ 1 altına alınan tezler de sosyal bilgiler öğretmenleri ile birlikte öğrencilerin de görüşüne başvuran araştırmacıların derse ilişkin tutum gibi farklı çevre ve süreçlerini içeren çalışmalara veli, öğrenci ve öğretmen gruplarını dâhil ettikleri görülmüştür. Dolayısıyla konunun bağlamı ve ilişkisine göre araştırmacıların öğretmenler dışında ek olarak farklı gruplarla çalıştıkları araştırmada elde edilen bir başka sonuçtur.

Araştırmacıların nicel yöntemli tezde en çok 101-300 arasında bir değerde örneklem grubu oluşturdukları görülürken; en az 34, en fazla 3019 kişi ile çalıştıkları görülmüştür. Nitel yöntemin kullanıldığı tezlerde ise araştırmacıların en çok 12-50 arasında bir değerde örneklem grubu oluşturdukları ve en az örneklem grubuna sahip tezde 6, en fazla örnekleme sahip tezde 153 kişi ile çalıştıkları görülmüştür. Karma yöntemin kullanıldığı tezlerde ise araştırmacıların 101-300 arasında örneklem grubu oluşturdukları görülürken en az örnekleme sahip tezde 12, en fazla örnekleme sahip tezde 1380 kişi ile çalıştıkları görülmüştür.

Sosyal bilgiler eğitimi alanında öğretmen görüşlerinin alındığı tezler veri analizi bağlamında incelendiğinde \%60'ında nicel veri analiz yöntemlerinin kullanıldığı görülürken \%23'ünde nitel veri analiz yöntemlerinin görülmektedir. Karma yöntemin kullanıldığı araştırmalarda ise kullanılan yöntemlere göre nitel ve nicel veri analiz teknikleri bir arada kullanılmıştır

Öneriler;

Sosyal bilgiler eğitimi alanında öğretmen görüşüne başvurulan tez çalışmalarının ağırlıklı olarak tematik açıdan incelendiği bu çalışmada, araştırmacıların bazı konular hakkında fazlaca öğretmen görüşü aldığı görülürken bazı konularda yeterli düzeyde çalışma ortaya koymadıkları görülmüştür. Sosyal bilgiler programı bir bütündür; fakat program yapısını oluşturan ögeler ve içerdiği konular ayrı ayrı değerlendirmeye tabi tutulmalıdır. Dolayısıyla az çalışılmış olan kazanım, beceri öğretimi, eğitim sistemine ilişkin güncel konular, öğretim teknolojileri ve materyal tasarımı, etkinlikler, TC İnkılap Tarihi ve Atatürkçülük, özel eğitim, sosyal bilgiler programının uygulanabilirliği, ödevler ve öğrenme ortamları gibi konu başlıkları öğretmenlerin gözünden ele alınmalıdır. Yalnızca bu konularla ilgili durum çalışmaları ortaya koymak sosyal bilgiler programının amaçlarına ulaşmak için yeterli olmayacağından ortaya çıkan sorunlara ve eksikliklere çözüm üretici öneriler getiren çalışmalar yapılmalıdır. 


\section{KAYNAKÇA}

Abbak, A. (2016). Sosyal bilgiler dersi harita okuma ve yorumlama becerisinin ögrretmen ve ögrenci görüşlerine göre incelenmesi. (Yayınlanmamış yüksek lisans tezi), Çukurova Üniversitesi, Sosyal Bilimler Enstitüsü, Adana.

Akmehmetoğlu, H. (2014). Sosyal bilgiler öğretmenlerinin sosyal bilgiler öğretiminde karşılaştıkları sorunlar (Kastamonu Il Örneği). (Yayınlanmamış yüksek lisans tezi), Kastamonu Üniversitesi, Sosyal Bilimler Enstitüsü, Kastamonu.

Aksoy, B., Sönmez, Ö., F. ve Merey, Z. (2009). Sosyal bilgiler öğretiminde yapılan lisansüstü tez konularının 2005 yeni sosyal bilgiler öğretim programına göre değişiminin değerlendirilmesi, IV, Sosyal Bilimler Ĕgitimi Kongresi, (9Ekim), İstanbul.

Akşit, İ. (2011). Illköğretimde görev yapan sosyal bilgiler öğretmenlerinin sosyal bilgiler öğretiminde karşılaştıkları sorunlar (Denizli ve Erzurum Örneği). (Yayınlanmamış yüksek lisans tezi), Pamukkale Üniversitesi, Sosyal Bilimler Enstitüsü, Denizli.

Aktaş, R. (2016). Sosyal bilgiler ögrretmenlerinin gezi-gözlem tekniğini kullanırken yaşadıkları problemler ve kazanımlara ilişskin görüşleri. (Yayınlanmamış yüksek lisans tezi), Kafkas Üniversitesi Sosyal Bilimler Enstitüsü, Kars.

Aktaş, S. (2010). İlköğretim II. kademe sosyal bilgiler derslerinde coğrafya konularının öğretimi: sorunlar ve çözüm önerileri. (Yayınlanmamış yüksek lisans tezi), Kilis 7 Aralık Üniversitesi Sosyal Bilimler Enstitüsü, Kilis.

Alataş, F. (2008). İlköğretim programında 4. ve 5. sınıf sosyal bilgiler öğretiminde karşılaşılan sorunlar, (Yayınlanmamış yüksek lisans tezi), Dokuz Eylül Üniversitesi Eğitim Bilimleri Enstitüsü, İzmir.

Arslan, M. (2016). Illkögretim sosyal bilgiler dersi müfredatında yer alan girişimcilik ve kariyer bilinci geliştirme becerilerinin ögretmen görüssleri doğrultusunda değerlendirilmesi. (Yayınlanmamış yüksek lisans tezi), Ağrı İbrahim Çeçen Üniversitesi, Sosyal Bilimleri Enstitüsü, Ağrı.

Ata, N. (2007). Illköğretim sosyal bilgiler dersinin kendimi tanıyorum ünitesindeki kazanımların ögrretmen görüşlerine göre değerlendirilmesi. (Yayınlanmamış yüksek lisans tezi), Gazi Üniversitesi Eğitim Bilimleri Enstitüsü, Ankara.

Ataman, M. (2007). Benzeşen ve ayrışan yönleriyle 1998 ve 2004 ilköğretim sosyal bilgiler öğretim programlarında (4.-5. sinfflar) ölçme ve değerlendirme yöntem ve teknikleri ve bunlara iliş̧in ögretmen görüşleri. (Yayınlanmamış yüksek lisans tezi), Marmara Üniversitesi Eğitim Bilimleri Enstitüsü, İstanbul.

Avcı, A., A. (2015). Sosyal bilgiler dersinde vatanseverlik değerinin kazandırılmasina yönelik ögretmen ve ögrenci görüşleri. (Yayınlanmamış yüksek lisans tezi), Kastamonu Üniversitesi Sosyal Bilimler Enstitüsü, Kastamonu.

Aydın, M. (2016). Bilgi ve iletişim teknolojilerinin sosyal bilgiler eğitiminde kullanılması hakkında ögrretmen görüşleri (Antalya İli Örneği). (Yayınlanmamış yüksek lisans tezi), Pamukkale Üniversitesi Eğitim Bilimleri Enstitüsü, Denizli.

Aydın, S. (2007). Illköğretim 4. ve 5.sinıf yeni (2004) sosyal bilgiler müfredatının öğretmen görüslerine göre değerlendirilmesi (Trabzon İl Örneği). (Yayınlanmamış yüksek lisans tezi), Sakarya Üniversitesi Sosyal Bilimler Enstitüsü, Sakarya.

Aydoğan, A. (2010). Sosyal bilgiler ögretmenlerinin sürdürülebilir kalkınma konusuyla ilgili kazanımların ögretimine ilişskin görüşler. (Yayınlanmamış yüksek lisans tezi), Niğde Üniversitesi Sosyal Bilimler Enstitüsü, Niğde.

Ayten, P. (2006). İlköğretim okullarında sosyal bilgiler dersini yürüten 4. ve 5. ögretmenlerinin sosyal bilgiler dersi öğretim programına ilişkin görüşleri. (Yayınlanmamış yüksek lisans tezi), Gazi Üniversitesi Eğitim Bilimleri Enstitüsü, Ankara.

Badem, S. (2012). İlköğretim 7. sinıf sosyal bilgiler programının ekonomi ve sosyal hayat ünitesindeki kazanımların gerçekleşme düzeyine ilişkin öğretmen görüşleri (Elazığ İli Örneği). (Yayınlanmamış yüksek lisans tezi), Firat Üniversitesi Eğitim Bilimleri Enstitüsü, Elazı̆̆.

Bahadır, Ö. (2016). Sosyal bilgiler öğretmenlerinin çok kültürlülük ve çok kültürlü eğitim algılarının değerlendirilmesi: Kocaeli Örneği. (Yayınlanmamış yüksek lisans tezi), Sakarya Üniversitesi Eğitim Bilimleri Enstitüsü, Sakarya.

Baki, Ç. (2012). 6. Ve 7. sinıf sosyal bilgiler dersi ögrenci çalışma kitaplarının kullanım durumlarının öğretmen ve ögrenci görüsllerine göre değerlendirilmesi: Rize örneği. (Yayınlanmamış yüksek lisans tezi), Karadeniz Teknik Üniversitesi Eğitim Bilimleri Enstitüsü, Trabzon.

Başaran, T. (2007). İlköğretim okullarında vatandaşlık ve insan hakları eğitimi programının uygulanışına ilişkin sosyal bilgiler ögrretmenlerinin görüşleri. (Yayınlanmamış yüksek lisans tezi), Trakya Üniversitesi Sosyal Bilimler Enstitüsü, Edirne. 
Başoğlu, M. (2009). Sosyal bilgiler 6. ve 7.sınıf öğretim programlarının ögrretmen ve ögrrenci görüşlerine göre değerlendirilmesi. (Yayınlanmamış yüksek lisans tezi), Dumlupınar Üniversitesi Sosyal Bilimler Enstitüsü, Kütahya.

Batmaca, K. (2016). Sınıf Öğretmenlerinin 4. sınıf sosyal bilgiler dersinde yer alan dĕgerlerin ögretimine ilişkin görüşleri. (Yayınlanmamış yüksek lisans tezi), Kafkas Üniversitesi Sosyal Bilimler Enstitüsü, Kars.

Bayram, H. (2012). Sosyal bilgiler dersinde alternatif ölçme değerlendirme yöntemi olarak portfolyo (ögrenci ürün) dosyası, performans ve proje görevi uygulamasına ilişkin ögretmen görüşleri. (Yayınlanmamış yüksek lisans tezi), Kilis 7 Aralık Üniversitesi Sosyal Bilimler Enstitüsü, Kilis.

Baysal, N. (2013). Ortaokul sosyal bilgiler derslerinde değerler eğitimi uygulamalarının öğretmenler yönüyle değerlendirilmesi. (Yayınlanmamış yüksek lisans tezi), Niğde Üniversitesi Eğitim Bilimleri Enstitüsü, Niğde.

Bozkurt, S. (2017). İlköğretim 6. sınıf sosyal bilgiler dersinde güncel olayların kullanımına ilişkin ögretmen ve ögrenci görüşleri. (Yayınlanmamış yüksek lisans tezi), Fırat Üniversitesi Eğitim Bilimleri Enstitüsü, Elazığ.

Can, Ö. (2008). Dördüncü ve beşinci sınıf ögretmenlerinin sosyal bilgiler dersinde değerler ĕ̆itimi uygulamalarına ilişkin görüşleri. (Yayınlanmamış yüksek lisans tezi), Hacettepe Üniversitesi Sosyal Bilimler Enstitüsü, Ankara.

Cendek, M. (2015). Öğrencilerde harita okuryazarlı̆̆ının geliştirilmesine ilişkin sosyal bilgiler öğretmenlerinin görüşleri. (Yayınlanmamış yüksek lisans tezi), Marmara Üniversitesi Eğitim Bilimleri Enstitüsü, İstanbul.

Creswell, J.W. (2016). Nitel araştırma yöntemleri beş yaklaşıma göre nitel araştırma ve nitel araştırma deseni (3.baskl), Mesut Bütün, Selçuk Beşir Demir (Çev. Ed.), Ankara: Siyasal.

Çakar, Ö. (2008). Illkögretim 5. sınıf sosyal bilgiler dersinin deprem bilinci geliştirmedeki rolüne dair ögretmen görüşleri. (Yayınlanmamış yüksek lisans tezi), Fırat Üniversitesi Sosyal Bilimler Enstitüsü, Elazı̆̆.

Çelik, F. (2010). 5. Sınıf sosyal bilgiler programında sorumluluk, estetik ve doğal çevreye duyarlılık değerlerinin kazandırılmasına ilişkin ögrenci ve öğretmen görüşleri. (Yayınlanmamış yüksek lisans tezi), Anadolu Üniversitesi Eğitim Bilimleri Enstitüsü, Eskişehir.

Çelik, H. (2009). Sosyal bilgiler ögrretmenlerinin vatandaşlık ĕgitiminin bugünkü durumu ve geleceğine ilişkin görüşleri. (Yayınlanmamış doktora tezi), Marmara Üniversitesi Eğitim Bilimleri Enstitüsü, İstanbul.

Çelik, S. (2016). Sosyal bilgiler dersi 7. sınıf öğretim programı 'yaşayan demokrasi' değerlendirilmesi. (Yayınlanmamış yüksek lisans tezi), Fırat Üniversitesi Eğitim Bilimleri Enstitüsü, Elazı̆̆.

Çetin, F. (2007). Illköğretim 4. sınıf sosyal bilgiler öğretim programının öğretmen görüşleri doğrultusunda değerlendirilmesi (Meram İlçesi Örneği). (Yayınlanmamış yüksek lisans tezi), Selçuk Üniversitesi Sosyal Bilimler Enstitüsü, Konya.

Demir, F. (2010). Sosyal bilgiler dersinde uygulanan etkinliklerin ögretmen görüşlerine göre değerlendirilmesi. (Yayınlanmamış yüksek lisans tezi), Dumlupınar Üniversitesi Sosyal Bilimler Enstitüsü, Kütahya.

Demir, M. (2014). Yeni ĕgitim sisteminde (4+4+4) 5.sınıf sosyal bilgiler dersi ile ilgili sosyal bilgiler ögretmenlerinin görüşleri (Balıkesir Örneği). Yüksek Lisans Tezi, Balıkesir Üniversitesi Sosyal Bilimler Enstitüsü, Balıkesir.

Ece, B. (2007). Illköğretim birinci kademe 2005 sosyal bilgiler programının öğretmen görüşlerine göre değerlendirilmesi (Afyonkarahisar İli Örneği). (Yayınlanmamış yüksek lisans tezi), Afyon Kocatepe Üniversitesi Sosyal Bilimler Enstitüsü, Afyonkarahisar.

Erdem, M. (2007). Sosyal bilgiler öğretmenlerinin gezi-gözlem tekniğine ilişkin görüşleri. (Yayınlanmamış yüksek lisans tezi), Gazi Üniversitesi Eğitim Bilimleri Enstitüsü, Ankara.

Erdoğdu, E. (2010). Sosyal bilgiler öğretmenlerinin kullandıkları yöntem/teknikler ve karşılaştıkları kullanım güçlükleri. (Yayınlanmamış yüksek lisans tezi), Dumlupınar Üniversitesi Sosyal Bilimler Enstitüsü, Kütahya.

Ergin, E. (2011). Çevre bilinci geliştirmede sosyal bilgiler dersinin rolüne ilişkin öğretmen görüşleri (Elazı̆̆ İli Örneği). (Yayınlanmamış yüksek lisans tezi), Fırat Üniversitesi Sosyal Bilimler Enstitüsü, Elazı̆̆.

Erköse, E. (2007). Yenilenen 6. sınıf sosyal bilgiler dersi ögretim programının sosyal bilgiler ögretmenlerinin görüşlerine göre değerlendirilmesi (Sakarya İli Örneği). (Yayınlanmamış yüksek lisans tezi), Sakarya Üniversitesi Sosyal Bilimler Enstitüsü, Sakarya.

Ersoy, A. (2007). Sosyal bilgiler dersinde ögretmenlerin etkili vatandaşlık eğitimi uygulamalarına ilişkin görüşleri. (Yayınlanmamış doktora tezi), Anadolu Üniversitesi Eğitim Bilimleri Enstitüsü, Eskişehir.

Geçit, Y. \& Kartal, A. (2010). Türkiye'deki sosyal bilgiler eğitimi araştırma konuları üzerine bir inceleme. International Conference on New Trends in Education and Their Implications (11-13 Kasim), Antalya.

Gezer, U. (2015). Sosyal bilgiler dersinde kariyer bilinci geliştirme: ögretmen görüş ve uygulamalarl. (Yayınlanmamış yüksek lisans tezi), Anadolu Üniversitesi Eğitim Bilimleri Enstitüsü, Eskişehir. 
Göç, N. (2008). Yerel tarih konularının sosyal bilgiler derslerinde uygulanması; karşılaşılan güçlükler ve çözüm önerileri (Yozgat Örneği). (Yayınlanmamış yüksek lisans tezi), Gaziosmanpaşa Üniversitesi Sosyal Bilimler Enstitüsü, Tokat.

Güler, E. (2016). Farklı yayın evlerine ait sosyal bilgiler ders kitaplarının ögrretmen görüşlerine göre incelenmesi (Muğla İli Örnĕgi). (Yayınlanmamış yüksek lisans tezi), Muğla Sitkı Koçman Üniversitesi Eğitim Bilimleri Enstitüsü, Muğla.

Hallaç, S. (2011). 6. sınıf sosyal bilgiler dersinde etkinliklerin uygulanmasında ögrretmen görüşleri. (Yayınlanmamış yüksek lisans tezi), Fırat Üniversitesi Eğitim Bilimleri Enstitüsü, Elazı̆̆.

Hatuk, M. (2010). Sosyal bilgiler öğretiminde portfolyoların kullanımına yönelik ögretmen görüşlerinin değerlendirilmesi. (Yayınlanmamış yüksek lisans tezi), Çukurova Üniversitesi Sosyal Bilimler Enstitüsü, Adana.

Kabak, N. (2009). Sosyal bilgiler ögretiminde performans dĕgerlendirmeye ilişkin ögretmen görüşleri (Manisa İli Örneği). (Yayınlanmamış yüksek lisans tezi), Dokuz Eylül Üniversitesi Eğitim Bilimleri Enstitüsü, İzmir.

Kahriman, M. (2008). 6. sınıf sosyal bilgiler programının coğrafya içerikli ünitelerine ilişkin sosyal bilgiler ögretmenlerinin görüşleri (Konya İli Örneği). (Yayınlanmamış yüksek lisans tezi), Selçuk Üniversitesi Sosyal Bilimler Enstitüsü, Konya.

Kalaycığlu, E. (2007). İlköğretim 4. ve 5. sınıf sosyal bilgiler programının ögretmen görüşlerine göre değerlendirilmesi. (Yayınlanmamış yüksek lisans tezi), Atatürk Üniversitesi Sosyal Bilimler Enstitüsü, Erzurum.

Kamber, T. (2007). 2005-2006 yeni öğretim programında sosyal bilgiler dersi etkinliklerinin uygulanabilirliğinin incelenmesi. (Yayınlanmamış yüksek lisans tezi), Afyon Kocatepe Üniversitesi Sosyal Bilimler Enstitüsü, Afyonkarahisar.

Kara Kılıç, K. (2016). Sosyal bilgiler öğretmenlerinin öğretim teknolojileri ve materyal kullanımına ilişkin görüşleri. (Yayınlanmamış yüksek lisans tezi), Uşak Üniversitesi Sosyal Bilimler Enstitüsü, Uşak.

Kara, C. (2013). 2004 İlkögrretim 7. sınıf sosyal bilgiler öğretim programındaki kazanımların ön-son test sonuçlarına ve ögretmen görüşlerine göre değerlendirilmesi. (Yayınlanmamış doktora tezi), Fırat Üniversitesi Eğitim Bilimleri Enstitüsü, Elazığ.

Karaca, S. (2017). Ortaokullarda görevli sosyal bilgiler öğretmenlerinin sosyal bilgiler öğretiminde karşılaştıkları sorunlar (Çorum İli Örneği). (Yayınlanmamış yüksek lisans tezi), Amasya Üniversitesi Sosyal Bilimler Enstitüsü, Amasya.

Karasar, N. (2010). Bilimsel araştırma yöntemi. Ankara: Nobel Yayın Dağıtım.

Karasu, E. (2012). Illkögretim 6. ve 7, sinıf sosyal bilgiler derslerinde yapılan proje çalışmalarının ögretmen ve ögrenci görüşlerine göre değerlendirilmesi (Kastamonu ili örneği). (Yayınlanmamış yüksek lisans tezi), Kastamonu Üniversitesi Sosyal Bilimler Enstitüsü, Kastamonu.

Kartal, M. (2017). Sosyal bilgiler öğretmenlerinin ĕgitim bilişim ă̆ı (eba) hakkındaki görüşleri. (Yayınlanmamış yüksek lisans tezi), Gaziosmanpaşa Üniversitesi Eğitim Bilimleri Enstitüsü, Tokat.

Kılcan, B. (2009). İlköğretim 6. sınıf sosyal bilgiler öğretim programında yer alan değerler öğretimine ilişkin ögretmen görüşleri 'Kırşehir ili örneği'. (Yayınlanmamış yüksek lisans tezi), Niğde Üniversitesi Sosyal Bilimler Enstitüsü, Niğde.

Kılıçoğlu, G. (2007). İlköğretim 4. ve 5. sınıf sosyal bilgiler programına ilişkin öğretmen görüşlerinin değerlendirilmesi (Kars İli Örneği). (Yayınlanmamış yüksek lisans tezi), Kafkas Üniversitesi Sosyal Bilimler Enstitüsü, Kars.

Kınasakal, İ. (2012). Ilköğretim 7. sınıf sosyal bilgiler programında yer alan değerlerin kazanılmışlık düzeyinin ögretmen görüşlerine göre değerlendirilmesi. (Yayınlanmamış yüksek lisans tezi), Kastamonu Üniversitesi Sosyal Bilimler Enstitüsü, Kastamonu.

Kulantaş, N. (2007). 4. ve 5. sınıf sosyal bilgiler dersinde kullanılan, ögrenci ders ve çalışma kitapları ile ögretmen kllavuz kitaplarının ögretmen, ögrenci ve veli görüşlerine göre değerlendirilmesi. (Yayınlanmamış doktora tezi), Gazi Üniversitesi Eğitim Bilimleri Enstitüsü, Ankara.

Nalçacı, A. (2006). ilköğretim 6. ve 7. sınıf sosyal bilgiler programındaki coğrafya konularının öğretmen ve ögrenci görüşlerine göre değerlendirilmesi. (Yayınlanmamış doktora tezi), Atatürk Üniversitesi Sosyal Bilimler Enstitüsü, Erzurum.

Oruç, Ş. ve Ulusoy, K. (2008). sosyal bilgiler alanında yapılan tez çalışmaları. Ahmet Keleşoğlu Eğitim Fakültesi Dergisi, 26, 121-132.

Özdal, H. (2007). İlköğretim 6.sınıf sosyal bilgiler dersi programında yer alan türkiye'miz ünitesinin öğretmen görüşlerine göre değerlendirilmesi. (Yayınlanmamış yüksek lisans tezi), Sakarya Üniversitesi Sosyal Bilimler Enstitüsü, Sakarya.

Özdemir, D. (2006). Sosyal bilgiler dersinin düşünme becerilerini kazandırma düzeyine ilişkin öğretmen görüşler. (Yayınlanmamış yüksek lisans tezi), Anadolu Üniversitesi Eğitim Bilimleri Enstitüsü, Eskişehir. 
Öztürk, S. (2009). İlköğretim okullarında yapılandırmacı yaklaşım doğrultusunda hazırlanan 6 ve 7. sınıf sosyal bilgiler dersi ögretim programına yönelik öğretmen görüşleri. (Yayınlanmamış yüksek lisans tezi), Kafkas Üniversitesi Sosyal Bilimler Enstitüsü, Kars.

Özünal, S. (2015). Sosyal bilgiler dersinde coğrafya konularının kimlik inşası ve vatandaşlık bilinci kazandırmasına ilişkin ögretmen görüşleri. (Yayınlanmamış doktora tezi), Dumlupınar Üniversitesi Eğitim Bilimleri Enstitüsü, Kütahya.

Pınarbaşı, D. (2007). İlköğretim 4. ve 5. sınıflarda eski ve yeni öğretim programına göre okutulan sosyal bilgiler ders kitaplarındaki coğrafya ünitelerine ilişkin ölçme ve değerlendirme çalışmalarının ögretmen görüşlerine göre analizi. (Yayınlanmamış yüksek lisans tezi), Çanakkale On sekiz Mart Üniversitesi Sosyal Bilimler Enstitüsü, Çanakkale.

Polat, F. (2006). İlköğretim 7. sınıf sosyal bilgiler öğretiminde öğretmenlerin kullandıklarl yöntemler ve karşılaştıkları sorunlar (Afyonkarahisar Örneği). Yüksek Lisans Tezi, Gazi Üniversitesi Eğitim Bilimleri Enstitüsü, Ankara.

Polat, L. (2012). İlköğretim 6. sınıf sosyal bilgiler dersi öğretim programının genel amaçlarına ulaşma düzeyine ilişkin ögretmen görüşleri: Elazı̆̆ İli Örneği. (Yayınlanmamış yüksek lisans tezi), Fırat Üniversitesi Eğitim Bilimleri Enstitüsü, Elazığ.

Safi, H. (2010). Sosyal bilgiler öğretim programında yer alan mekânı algılama becerisinin geliştirilmesi hakkında ögretmen görüşleri. (Yayınlanmamış yüksek lisans tezi), Marmara Üniversitesi Eğitim Bilimleri Enstitüsü, İstanbul.

Sağlam, E. (2014a). beşinci sınıf sosyal bilgiler dersi öğretim programı ile ilgili öğretmen görüşlerinin değerlendirmesi. (Yayınlanmamış yüksek lisans tezi), Erzincan Üniversitesi Sosyal Bilimler Enstitüsü, Erzincan.

Sağlam, E. (2014b). İlkokul 4. sınıf sosyal bilgiler programında belirlenen değerlerin kazanım düzeyleri ve bu süreçte karş̧laşılan güçlüklerin değerlendirilmesi. (Yayınlanmamış yüksek lisans tezi), Çanakkale On sekiz Mart Üniversitesi Eğitim Bilimleri Enstitüsü, Çanakkale.

Salik, G. (2007). Sosyal bilgiler dersinde coğrafya konularının öğretiminde karşılaşılan sorunlar ve çözüm önerilerine ilişkin öğretmen görüşleri. (Yayınlanmamış yüksek lisans tezi), Anadolu Üniversitesi Eğitim Bilimleri Enstitüsü, Eskişehir.

Sayar, P. (2016). Sosyal bilgiler dersinde branş derslik sistemi uygulamasının ögretmen, öğrenci ve idareci görüşlerine göre değerlendirilmesi. (Yayınlanmamış yüksek lisans tezi), Bartın Üniversitesi Eğitim Bilimleri Enstitüsü, Bartın.

Şahin, S. (2010). Illköğretim sosyal bilgiler 5. sınıf ders kitaplarının öğretmen görüşleri doğrultusunda değerlendirilmesi. (Yayınlanmamış yüksek lisans tezi), Fırat Üniversitesi Sosyal Bilimler Enstitüsü, Elazı̆̆.

Şahin, M., Yıldız, D. ve Duman, R. (2011). Türkiye'de sosyal bilgiler eğitimi tezleri üzerine bir değerlendirme. Journal of Social Studies Education Research, 2 (2), 96-121.

Şan, A. (2016). Ortaokul sosyal bilgiler derslerinde çevre gezilerinin etkililiği üzerine ögretmen görüşlerinin incelenmesi (Antalya İli Örnĕ̌i). (Yayınlanmamış yüksek lisans tezi), Akdeniz Üniversitesi Eğitim Bilimleri Enstitüsü, Antalya.

Tahiroğlu, M. (2006). ilköğretim okullarının ikinci kademesinde sosyal bilgiler dersi ögretmenlerinin, sosyal bilgiler dersi öğretiminde karşılaştıkları güçlükler (Aksaray İli Örneği). (Yayınlanmamış yüksek lisans tezi), Selçuk Üniversitesi Sosyal Bilimler Enstitüsü, Konya.

Tarman, B., Acun, İ. ve Yüksel, Z. (2010). Sosyal bilgiler eğitimi alanındaki tezlerin değerlendirilmesi, Gazi Üniversitesi Sosyal Bilimler Dergisi, 9(3), 725-746.

Taş, T, A.,(2015). sosyal bilgiler ders kitabı etkinliklerinin öğretmen görüşleri doğrultusunda değerlendirilmesi: Yatağan Örneği. (Yayınlanmamış yüksek lisans tezi), Muğla Sıtkı Koçman Üniversitesi Eğitim Bilimleri Enstitüsü, Muğla.

Taşkın, M. (2017). Ortaokul sosyal bilgiler ders kitaplarında kullanılan görsellerin ögrretmen görüşlerine göre incelenmesi. (Yayınlanmamış yüksek lisans tezi), İstanbul Üniversitesi Eğitim Bilimleri Enstitüsü, İstanbul.

Tay, B. (2017). 2005 Sosyal bilgiler dersi öğretim programı ile 2017 sosyal bilgiler dersi taslak öğretim programının karşılaştırması. International Journal of Eurasia Social Sciences, (8)27, 461-487.

Tepecik, B. (2008). Sosyal bilgiler dersinde sorumluluk değerinin kazandırılmasına ilişkin öğretmen görüşleri. (Yayınlanmamış yüksek lisans tezi), Anadolu Üniversitesi Eğitim Bilimleri Enstitüsü, Eskişehir.

Turan, E. (2010). Illköğretim birinci kademe sosyal bilgiler derslerinde kullanılan ölçme değerlendirme yöntemlerinin öğretmen görüşlerine göre değerlendirilmesi. (Yayınlanmamış yüksek lisans tezi), Gazi Üniversitesi Eğitim Bilimleri Enstitüsü, Ankara.

Uçar, S. (2009). Sosyal bilgiler programındaki değerlerle ilgili kazanımlara yönelik öğretmen görüşlerinin değerlendirilmesi. (Yayınlanmamış yüksek lisans tezi), Çukurova Üniversitesi Sosyal Bilimler Enstitüsü, Adana. 
Urçar, A. (2011). Altıncı sınıf sosyal bilgiler ders kitabında yer alan coğrafya konularının öğretim sürecine yönelik öğretmen görüşlerinin incelenmesi (Erzurum İli Aşkale İlçesi Örneği). (Yayınlanmamış yüksek lisans t ezi), Atatürk Üniversitesi Eğitim Bilimleri Enstitüsü, Erzurum.

Yazar, O. (2008). İlkögrretim 4. ve 5. sınıf sosyal bilgiler dersi ögretim programına ilişkin ögretmen görüşlerinin incelenmesi. (Yayınlanmamış yüksek lisans tezi), Atatürk Üniversitesi Sosyal Bilimler Enstitüsü, Erzurum.

Yıldırım, A.\& Şimşek, H. (2016). Sosyal bilimlerde nitel araştırma yöntemleri (Genişletilmiş 10.baskı). Ankara: Seçkin.

Yıldırım, G. (2007). Sosyal bilgiler ögretmenlerinin ders denetimine ilişkin görüşleri (Denizli İli Örneği). (Yayınlanmamış yüksek lisans tezi), Muğla Üniversitesi Sosyal Bilimler Enstitüsü, Muğla.

Yıldız, A. (2005). İlköğretim 7. sınıf sosyal bilgiler ders kitaplarının niteliğinin ve bununla ilgili ögretmen-ögrenci görüşlerinin değerlendirilmesi. (Yayınlanmamış yüksek lisans tezi), Marmara Üniversitesi Eğitim Bilimleri Enstitüsü, İstanbul.

Yıldızhan, N. (2010). İlköğretim 4. ve 5. sınıf sosyal bilgiler dersi ögretmen kılavuz kitabının ögretmen görüşleri doğrultusunda değerlendirilmesi. (Yayınlanmamış yüksek lisans tezi), Gazi Üniversitesi Eğitim Bilimleri Enstitüsü, Ankara.

Yılmaz, S. (2014). 6. sınıf sosyal bilgiler öğretmen kllavuz kitaplarının kullanım durumlarının öğretmen görüşlerine göre değerlendirilmesi (Ordu İli Örneği). (Yayınlanmamış yüksek lisans tezi), Giresun Üniversitesi Sosyal Bilimler Enstitüsü, Giresun. 


\section{EXTENDED ABSTRACT}

\section{Introduction}

With the technological, social, economic and political steps taken with each passing day, the education system is also turning to new ways. Therefore, the training programs, which are the implementation plan of the education system, are among the most affected by these developments.

One of the fundamental changes that included training programs was in 2005. With the adoption of the constructivist approach, social constructivism reflected in the social studies program has prepared many changes. The elimination of commitment to the single textbook, the creation of units with themes, the acquisition of skills and values throughout the program, the adoption of the process of alternative measurement and evaluation based on the process, and the exemplary activities designed for each achievement (Tay, 2017) have made the program more feasible and interactive with stakeholders.

One of the most important stakeholders in the program creation and implementation process is undoubtedly the teachers who are the practitioners of the program. Therefore, teachers and their opinions for researchers are one of the richest data sources that show the results of the social studies program that was renewed in 2005, the pros, the points that need to be re-emphasized. From this point of view, it is important to examine the topics that the researchers tend to take the opinions of teachers in social studies education.

\section{Method}

The aim of this social study is to reveal the tendencies of postgraduate theses according to the teachers' in Turkey between 2005-2018 years of research in the field of social studies education. Within the framework of this general purpose, the studies that were carried out according to the opinions of teachers were classified according to themes, years, universities, methods, sample size and size and data analysis techniques. The research was conducted in accordance with descriptive survey model.

Content analysis was used to collect the research data. From the result of scanning "social studies" and "teacher opinions" keywords in the National Thesis Center page were obtained 58 thesis. Since this number was not thought to give all of the theses presented in line with the opinions of the teachers, so only with "social studies" keywords were searched and 1253 theses were found. First 1253 thesis was graded by date, 202 thesis given before 2005 was held out of first research. The remaining 1051 were examined in detail according to the thesis headings, and 885 theses which were not included in the research subject were also taken out. The theses which were revealed by taking teacher opinion, parent and student opinion were excluded from the study. Following the process of the theses in the system in the classification form, 20 general titles were determined according to the topics of 167 theses. The title of each thesis was written to the classification form and expert opinion was consulted. In line with the expert opinions, 2 more titles added and 10 thesis were taken under these titles. Then each title is given a code and the theses are re-classified according to these codes. In addition, according to the sub-objectives of the study, theses are classified separately according to the year, level, method, sample size, sample group and data analysis method. The data obtained after the completion of the classification process were first interpreted around the main purpose and then around the sub-objectives.

\section{Findings, Discussion and Results}

As a result of the research, it is seen that $93 \%$ of the theses referenced teachers' opinions in the field of Social Studies Education are master and $7 \%$ of them are doctoral thesis. While the researchers' desire to introduce new contents at different Ph.D. and research groups lead them to different topics and research groups, it is possible to say that the researchers who made graduate studies tend to have more tendencies to think about teachers because they are expected to apply the scientific research process correctly rather than producing graduate level content.

When the distributions of the theses were examined, it was found out that the researchers mostly applied to teachers' opinions on "social studies program"," problems in teaching social studies", ,Assesment and evaluation" and 'books'". In Tarman, Acun and Yüksel (2010) reasearch they found that the theses given in the field of social studies education mostly focused on social studies program, difficulties encountered in social studies teaching and textbook studies. Researchers, who took the opinions of students, teachers and parents as a topic in the same study, underlined that much thesis has been put forward in this chapter until 2010. Likewise, in the study of Geçit and Kartal (2010), it was seen that the researchers working in the field of social studies education had a greater tendency to study social studies and book studies.

Interdiscipline gains, skills teaching, teaching of geography subjects, education system, teaching methods and techniques, teaching technologies and material design, teaching of social studies, activities, teaching of history 
subjects, History of Turkish Revolution and Kemalism, special education, applicability of social studies program It was found out that they preferred less about teachers' opinions in terms of assignments, learning environments, attitudes towards courses and teaching concepts. Because of not having much work on special education and learning environments in the context of social studies education, and the fact that the students' opinions on the attitudes and assignments related to the course are more than the teachers can be shown among the reasons of this situation.

Oruç and Ulusoy (2008) in their study on the study of social studies in the field of the study of the concept teaching, material use, value-skills are emphasized that the study of the subjects are very little. When the distribution of the theses according to the teachers' opinions in the field of Social Studies Education is examined, it is seen that the most thesis in the context of both master and doctorate thesis is from Gazi University. The other universities with a very low number of doctoral theses are Atatürk University, Afyon Kocatepe University, Bolu Abant İzzet Baysal University, Dumlupinar, Marmara and Firat Universities. In the research findings of Şahin, Yıldız and Duman (2011), the number of theses given in universities such as Gazi, Marmara and Atatürk is found to be quite high compared to other universities.

While it is seen that the qualitative methods are used every year between the years 2005-2017, it is revealed that the theses that were studied in qualitative method have been given since 2006 and that the tendency towards qualitative methods has increased gradually since 2012. The theses using mixed methods have been observed since 2007 and it has been observed that it reached its highest level in 2014 after nearly seven years. Therefore, it is observed that the theses put forth by using mixed methods have the biggest ratio and the qualitative studies have also increased.

In the research, it was seen that social studies teachers formed the first place in the distribution of the preferred sample groups in the theses put forth by applying the opinion of teachers in the field of social studies education. As the program is being implemented in the first and second stages, the primary school teachers who are teaching social studies in the first level constitute the sample group that the researchers prefer second. Theses taken under the title of homeworks and textbooks were found to involve parents, students and teacher groups in the studies including social studies teachers and the opinions of the students. Therefore, according to the context of the subject and the relationship between researchers beside teachers additionally working with different groups is another result obtained in the research.

While it is seen that the researchers form a sample group with a value between 101-300 in the quantitative method thesis; It was observed that they work with at least 34, maximum 3019 people. In the theses using the qualitative method, it was found that the researchers formed a sample group with a maximum number of 12-50 and the study group had a sample with a minimum sample size of 6 and the study group had 153 students. In the theses using the mixed method, it was observed that the researchers formed a sample group of 101-300, while it was seen that they worked with 1380 people in the thesis with the least sampling and the lowest sample.

When the theses taken from the teachers' opinions in the field of social studies education are examined in the context of data analysis, it is seen that the quantitative data analysis methods are used in $60 \%$, while the qualitative data analysis methods are seen in $23 \%$. Qualitative and quantitative data analysis techniques are used in the researches in which mixed method is used.

In this study, where the thesis studies on social studies education which were consulted to teachers 'opinions were examined mainly from the thematic point of view, it was seen that the researchers received a lot of teachers' opinions about some subjects and they did not reveal enough studies in some subjects. The social studies program is a whole; however, the elements of the program structure and the subjects should be evaluated separately. Consequently, topics such as low-gain acquisition, skills training, current issues related to education system, instructional technologies and material design, activities, TC Revolution History and Kemalism, special education, applicability of social studies program, homework and learning environments should be considered from the teachers' point of view. Merely, to bring out the case studies will not be sufficient to reach the objectives of the social studies program, in order to bring solutions to the problems and deficiencies, should be done studies including recommendations which generate a solution. 


\section{ETIK BEYANNAME}

Yapulan bu arasttrmanun yazım siirecinde bilimsel ve etik kurallara tijun araz̧tırnactlar

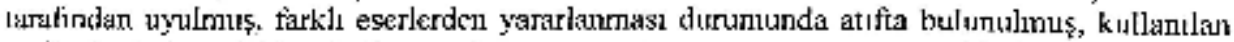

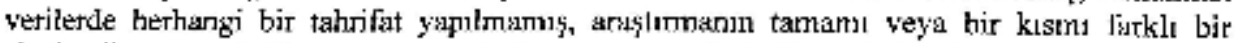
akademjk yayın platiomunda yayılatılrak ü/ere göndcrilmemiştir. Tūm bu durımlardan araștimada ismi bulunan yazarlarn bilgisi olkuğunu ve gerekli kurallara uyuldığ unu beyan cerim. $03 / 03 / 2020$

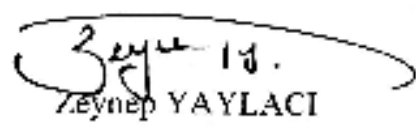

Araștınnanun Sotumlu Yazañ 